\title{
Stanowisko Iranu wobec konfliktu w Górskim Karabachu - zarys problematyki
}

pory terytorialne bezsprzecznie stanowią zagrożenia dla ładu i bezpieczeństwa
międzynarodowego. Historia wielokrotnie pokazywała, że z założenia niegroźny spór o przynależność danego terytorium może przyczynić się do eskalacji konfliktu na skalę międzynarodową. Niemniej, spory terytorialne stanowią zagrożenie dla bezpieczeństwa państw ościennych stron zaangażowanych w konflikt. Za bardzo dobry przykład takiego stanu rzeczy można uznać pozycję Islamskiej Republiki Iranu wobec konfliktu o Górski Karabach między Armenią a Azerbejdżanem.

Specyficzne położenie geopolityczne Iranu oraz sytuacja wewnątrz państwa, szczególnie w kontekście znaczącego zróżnicowania etnicznego warunkuje fakt, że każda zmiana w obrębie państwa ościennych wpływa na bezpieczeństwo Islamskiej Republiki Iranu. Iran w swojej historii stał się już ofiarą konfliktu na tle przynależności terytorialnej, gdy w 1980 roku Irak dokonał agresji na Iran w wyniku sporu o Szatt al-Arab. Kwestia przynależności Górskiego Karabachu nie jest obojętna władzom irańskim od kilkudziesięciu lat. Oprócz problematycznej kwestii udzielenia poparcia któreś ze stron sporu, dla Iranu wyzwaniem jest funkcjonowanie na swoim terytorium mniejszości azerskiej, która od lat wzywa do odłączenia irańskiej części Azerbejdżanu i przyłączenia jej do Republiki Azerbejdżanu. Wszelkie sytuacje konfliktowe między Armenią a Azerbejdżanem dotyczące Górskiego Karabachu stanowią impuls dla irańskich Azerów do podjęcia bardziej zdecydowanych działań na rzecz połączenia ze swoimi braćmi w Azerbejdżanie.

Powyższemu zagadnieniu jest poświęcony niniejszy artykuł: stanowisku Iranu wobec konfliktu o Górski Karabach. Wśród najważniejszych pytań badawczych dotyczących tego zagadnienia należy wymienić: Jak zmieniało się stanowisko Teheranu wobec powyższego konfliktu? Jakie działania podejmowały irańskie władze w celu zapobiegnięciu eskalacji przemocy? Jaki wpływ na bezpieczeństwo Iranu mają irańscy Azerowie? Jakie zagrożenia i wyzwania dla bezpieczeństwa Islamskiej Republiki Iranu ma spór między Armenią a Azerbejdżanem? Za główną hipotezę artykułu można uznać stwierdzenie, że Iran od 
kilkudziesięciu lat stanowi jednego $\mathrm{z}$ najważniejszych mediatorów $\mathrm{w}$ sporze o Górski Karabach. W niniejszym artykule w celu analizy powyższego problemu zostały wykorzystane następujące metody badawcze: analiza historyczna, metoda decyzyjna oraz synteza.

Artykuł został podzielony na trzy części. W pierwszej części zostało przedstawione stanowisko Iranu wobec problematyki Górskiego Karabachu w XX wieku, ze szczególnym uwzględnieniem lat 90. XX wieku po rozpadzie ZSRR. Druga część stanowi zarys polityki Teheranu wobec spornego obszaru w czasie dwóch pierwszych dekad XXI wieku. Trzecia część z kolei odnosi się do wydarzeń, do których doszło w 2020 roku w Górskim Karabachu i stanowiska Iranu wobec sytuacji w regionie w tamtym okresie.

\section{Górski Karabach w polityce Iranu w XX wieku}

Na początku należy wskazać powody przez które kwestia sporu o Górski Karabach jest tak istotna dla władz w Teheranie. Za główną przyczynę zainteresowania tym problemem przez Iran uznaje się działania militarne prowadzone w tym regionie, które niejednokrotnie zbliżały się do granic Islamskiej Republiki Iranu. Dla Teheranu wszystkie działania zbrojne prowadzone przy jego granicach są uznawane za bezpośrednie zagrożenie dla bezpieczeństwa narodowego oraz bezpieczeństwa jego interesów w regionie. Drugą przesłanką irańskiego zaangażowania w spór o Górski Karabach jest problem bezpieczeństwa w rejonie Morza Kaspijskiego, szczególnie jeśli chodzi o kwestie polityki energetycznej. W sytuacji zachwiania stabilności w tym obszarze, Iran obawiałby się potencjalnego zaangażowania Federacji Rosyjskiej, która dążyłaby do rozwiązania kwestii spornych bez wzięcia pod uwagę interesów Teheranu ${ }^{453}$. Kolejnym czynnikiem jest problem w relacjach Iranu z Armenią i Azerbejdżanem. Iran i Azerbejdżan łączy przynależność do tego samego odłamu islamu szyizmu, co jednak nie stanowi przesłanki do udzielania oficjalnego wsparcia Baku w sporze o Górski Karabach. Teheran udzielając poparcia Armenii odczuwa obawy wynikające z rosnącego zainteresowania irańskich Azerów, co do połączenia irańskich ostanów Azerbejdżan Wschodni i Azerbejdżan Zachodni dla Republiki Azerbejdżanu. Skutkowałoby to nie tylko zmianami granic Iranu, ale także zachwianiem równowagi w regionie. Ostatnią przyczyną działań Teheranu jest obawa przed napływem dużej liczny uchodźców na

\footnotetext{
453 Teheran dąży do uzyskania równego podziału dostępu do Morza Kaspijskiego między pięcioma zainteresowanymi państwami, natomiast Baku jest zwolennikiem podziału ze względu na długość linii brzegowej. Zob. M. Franz, Czy Azji grozi kolejna wojna, tym razem w basenie Morza Kaspijskiego?, „Nowa Polityka Wschodnia" 2013, nr 2, s. 54-60.
} 
terytorium Iranu, co przyczyniłoby się do zmiany struktury społecznej społeczeństwa oraz pogorszenia sytuacji gospodarczej państwa ${ }^{454}$.

Sam konflikt armeńsko-azerbejdżański sięga lat 20. XX wieku, kiedy to Górski Karabach został włączony do Azerbejdżańskiej Socjalistycznej Republiki Radzieckiej. Ormianie na terytorium Kaukazu Południowego znaleźli się po wojnie rosyjsko-perskiej trwającej w latach 1826-1828. Doszło wówczas do wymieszania się ludności pochodzenia perskiego i osmańskiego, a ponadto Rosja opowiadała się za chrystianizacją tego regionu, co skutkowało przesiedleniem Ormian z terenów Persji na Kaukaz ${ }^{455}$.

Do XX wieku nie dochodziło do bezpośrednich starć między Ormianami a Azerami. Dopiero w chwili wysiedlenia przez Rosję Ormian z terenów Persji i Imperium Osmańskiego na ziemiach zabranych od muzułmanów, w 1905 roku doszło do walk między muzułmanami a chrześcijanami ${ }^{456}$. Konflikt o Górski Karabach obejmuje ponad 20\% powierzchni całego Azerbejdżanu i stanowi wyzwanie dla całego regionu Kaukazu Południowego. Jeszcze w czasie istnienia Związku Radzieckiego, Azerowie i Ormianie odrzucili możliwość współistnienia obu grup w jednym państwie. Pod koniec lat 80. XX wieku doszło do wypędzenia Azerów Górno-Karabaskiego Obwodu Autonomicznego, a następnie Azerów zamieszkujących Armenię. Wraz z rozpadem ZSRR konflikt azersko-ormiański wszedł w nową fazę. Do jednego z najpoważniejszych kryzysów między Armenią a Azerbejdżanem doszło w 1988 roku, kiedy to Rada Delegatów Górnego Karabachu przyjęła rezolucję o zjednoczeniu z Armenią. Decyzja Górnego Karabachu skutkowała masakrą Ormian przez Azerów ${ }^{457}$. Należy pamiętać, że region Górskiego Karabachu nigdy nie należał do spokojnych i bezpiecznych, ale w okresie zimnej wojny, Związek Radziecki starał się ukrywać przypadki ataków na tle narodowościowym, przypisując im charakter przestępstw kryminalnych ${ }^{458}$.

19 stycznia 1990 roku Michaił Gorbaczow podpisał dekret wprowadzający w Baku stan wyjątkowy, o którym Azerowie nie zostali poinformowani, co skutkowało chaosem wśród azerskiej ludności cywilnej. Wywołało to reakcję Iranu, którego 160 z 270 parlamentarzystów zasiadających w Madżlesie wysłało list do rosyjskiego przywódcy, w którym wyrazili

\footnotetext{
${ }^{454} \mathrm{C}$. Mahmudlu, S. Abilov, The peace-making process in the Nagorno-Karabakh conflict: why did Iran fail in its mediation effort?, „, Journal of Contemporary Central and Eastern Europe” 2018, nr 26, s. 37-38.

${ }^{455}$ W 1978 roku wzniesiono we wsi Maraga pomnik upamiętniający przesiedlenie Ormian z Iranu na Kaukaz. Zob. R. Mechtijew, Dziesięć lat, które zmienily Azerbejdżan 2003-2013, Toruń 2016, s. 166-168.

456 D. Tarasiuk, Procesy narodowotwórcze, narody i problemy narodowościowe $w$ regionie [w:] Wprowadzenie do studiów wschodnioeuropejskich. Tom 4. Armenia, Azerbejdżan, Gruzja - przeszłość i teraźniejszość, M. Korzeniowski, D. Tarasiuk, K. Latawiec (red.), Lublin 2013, s. 171-172.

457 J. Modrzejewska-Leśniewska, Konflikt armeńsko-azerbejdżański 1990-2006 [w:] Konflikty kolonialne i postkolonialne w Afryce i Azji 1869-2006, P. Ostaszewski (red.), Warszawa 2006, s. 557-558.

${ }^{458}$ P. Kwiatkiewicz, Azerbejdżan: uksztaltowanie niepodleglego państwa, Toruń 2009, s. 73.
} 
niepokój o politykę Kremla wobec ludności muzułmańskiej ${ }^{459}$. Po ogłoszeniu 2 września 1991 roku niepodległości Górskiego Karabachu Iran próbował stworzyć swoją strefę wpływów w Azerbejdżanie wspierając mniejszość Tałyszy, stanowiącą lud pochodzenia irańskiego. W 1993 roku Islamska Republika Iranu zainicjowała utworzenie autonomicznej republiki Tałysz-Mughan. Ponadto, Iran próbował wpłynąć na szyickich Azerów dzięki swoim emisariuszom, którzy mieli namawiać ubogie azerskie rodziny do posyłania swoich dzieci do irańskich szkół koranicznych ${ }^{460} .29$ grudnia 1991 roku przeprowadzone zostało referendum niepodległościowe w Azerbejdżanie, które zatwierdziło niepodległość państwa. Iran wraz z Turcją, Pakistanem czy Stanami Zjednoczonymi był w grupie państw, które uznawały niepodległość Azerbejdżanu jeszcze przed referendum. Po upadku Suszy w maju 1992 roku, pełniący obowiązki prezydenta Azerbejdżanu, Jakub Mamedow zaapelował do Rosji i państw muzułmańskich w regionie o użycie ich autorytetu do zapobiegnięcia nowemu ludobójstwu na Azerach, aneksji jego ziem oraz zmiany granic Azerbejdżanu przez władze w Baku.

Iran aktywnie uczestniczy $w$ rozmowach między Armenią i Azerbejdżanem od 1992 roku, gdy ONZ poparł udział Teheranu jako mediatora w konflikcie. Islamska Republika Iranu wraz z Konferencją Bezpieczeństwa i Współpracy w Europie i przy wsparciu Rady Bezpieczeństwa rozpoczęła prowadzenie rozmów pokojowych. Zaangażowanie Iranu w proces pokojowy wynikało z faktu, że Azerowie są jedną z licznych grup zamieszkujących Islamską Republikę Iranu i Teheran nie mógł być bierny wobec wydarzeń w Azerbejdżanie, niezależnie od relacji łączących Teheran i Baku. W czasie procesu pokojowego Iran nie udzielał wsparcia Azerbejdżanowi, ale także powstrzymał się od oficjalnego wsparcia dla Armenii. Zastępca ministra spraw zagranicznych Iranu, Mahmud Vaezi oznajmił w tamtym okresie, że Teheran uznaje Górski Karabach za integralną część Azerbejdżanu ${ }^{461}$.

W marcu 1992 roju w Teheranie zorganizowano spotkanie przedstawicieli Armenii i Azerbejdżanu w celu rozpoczęcia rozmów pokojowych, w tym zawieszenia broni i wymiany więźniów. 15 marca 1992 roku zawarto w Teheranie porozumienie o wstrzymaniu działań wojennych, które trwało 7 dni. W maju 1992 roku w Teheranie rozpoczęly się kolejne

\footnotetext{
${ }^{459}$ Ibidem, s. 150-157.

${ }^{460}$ A. Curanović, Religie, kościoly i konflikty międzywyznaniowe w regionie Kaukazu [w:] Wprowadzenie do studiów wschodnioeuropejskich. Tom 4. Armenia, Azerbejdżan, Gruzja - przeszłość i teraźniejszość, M. Korzeniowski, D. Tarasiuk, K. Latawiec (red.), Lublin 2013, s. 220.

${ }^{461}$ P. Kwiatkiewicz, Azerbejdżan: uksztaltowanie..., op.cit., s. 230-233.
} 
rozmowy pokojowe między stronami. Podpisano wówczas trójstronne porozumienie o wstrzymaniu ognia i odblokowaniu komunikacji między krajami ${ }^{462}$.

Azerbejdżan jako państwo muzułmańskie, które znajduje się na geopolitycznym skraju cywilizacji islamskiej utrzymywał dobre relacje z Islamską Republiką Iranu, szczególnie w zakresie współpracy w Islamskiej Organizacji Współpracy. Relacje Azerów z Persami naznaczone były względami historycznymi, które powodują chwilowe napięcia między państwami, szczególnie w zakresie budowania ładu regionalnego i budowania wzajemnych relacji ${ }^{463}$. Nie zmieniło to jednak fakt, że azerski prezydent, Ilcham Alijew wielokrotnie podkreślał, że Azerbejdżan nigdy nie udostępni swojego terytorium dla państw, które planują dokonać ataku militarnego na jego sąsiadów ${ }^{464}$. Wydaje się, że Islamska Republika Iranu powinna wspierać Azerbejdżan, którego obywatele również są wyznawcami szyizmu, zwłaszcza, że Azerbejdżan sąsiaduje z Kaukazem Północnym, który źródłem radykalnych doktryn sunnickich, a to $\mathrm{z}$ kolei zagraża rządom obu państw. Brak wsparcia dla azerskich muzułmanów wynika $\mathrm{z}$ tego, że $\mathrm{w}$ czasie zimnej wojny duchowieństwo muzułmańskie w Azerbejdżanie było podporządkowane aparatowi państwowemu. Negatywny wpływ na relacje azersko-irańskie mają też stosunki Baku z Izraelem, więc w sporze między Armenią a Azerbejdżanem o Górski Karabach, Teheran wspiera chrześcijańską Armenię, co wynika z idei zapoczątkowanej przez Chomeiniego, które głosi obronę słabszych i prześladowanych ${ }^{465}$. Dla Iranu zagrożeniem płynącym z konfliktu o Górski Karabach jest problem azerskich uchodźców. Gdy w 1993 roku Armenia zaczęła zajmować tereny nadbrzeżne Araksu, rzeki oddzielającej Iran i Azerbejdżan, ponad 200 tysięcy Azerów ciekło do Islamskiej Republiki Iranu. Wyzwaniem dla władz irańskich było nie tylko zapewnienie im pomocy humanitarnej, a obawa przed rozbudzeniem aspiracji niepodległościowych Azerów zamieszkujących północny Iran, którzy w przeszłości wielokrotnie występowali przeciwko władzom irańskim. Irańska armia w celu stworzenia strefy bezpieczeństwa przekroczyły granicę z Azerbejdżanem 2 września 1993 roku i stworzyła tam obozy dla azerskich uchodźców ${ }^{466}$. Poparcie Iranu dla rozwiązania konfliktu między Armenią a Azerbejdżanem było widoczne w zaangażowaniu władz irańskich w ochronę zabytków i dziedzictwa narodowego na terenach objętych konfliktem. Na prośbę Kościoła ormiańskiego

\footnotetext{
${ }^{462}$ P. Adamczewski, Górski Karabach w polityce niepodleglego Azerbejdżanu, Warszawa 2012, s. 361-362.

${ }^{463}$ M. Franz, Czy Azji grozi kolejna wojna..., op. cit., s. 54-60.

${ }^{464}$ R. Mechtijew, Dziesięć lat, które..., op. cit., s. 156-157.

${ }^{465}$ M. Rzepka, Polityka zagraniczna Islamskiej Republiki Iranu [w:] Wprowadzenie do polityki zagranicznej muzutmańskich państw Bliskiego Wschodu i Afryki Pótnocnej, M. Woźniak-Bobińska, A. M. Solarz (red.), Warszawa 2018, s. 205.

${ }^{466}$ P. Kwiatkiewicz, Azerbejdżan: ukształtowanie..., op.cit., s. 307-309.
} 
konserwatorzy zabytków z Iranu mieli podjąć się odrestaurowania meczetu w Szuszy, czemu jednak sprzeciwił się rząd azerbejdżański. Azerbejdżan przeciwstawiał się irańskiemu zaangażowaniu w ochronę kultury na terenach Górskiego Karabachu, ponieważ obawiał się przypisania Armenii wszystkich zasług w tym zakresie. Za to Erywań chętnie korzystało $\mathrm{z}$ pomocy Teheranu przy odbudowie muzułmańskich zabytków na swoim terytorium ${ }^{467}$.

XX wiek, a szczególnie lata 90. To okres, w którym Islamska Republika Iranu próbowała dostosować się do nowopowstałego ładu geopolitycznego po upadku Związku Radzieckiego i powstania nowych oraz niepodległych państw tuż przy jej granicach. Konflikt zbrojny przy granicach niestabilnej Islamskiej Republiki Irańskiej, która zmagała się z wewnętrznym kryzysem spowodowanym wojną iracko-irańską, falą afgańskich uchodźców czy też sankcjami międzynarodowymi stanowił realne zagrożenie dla Teheranu. Skutkowało to koniecznością zwiększenia aktywności dyplomatycznej władz irańskich, tak aby jak odsunąć w czasie potencjalny konflikt zbrojny. Ponadto, skupienie się na pomocy w zakresie zapewnienie bezpieczeństwa społeczno-kulturowego problematycznego regionu jednoznacznie wskazuje, że Islamska Republika Iranu w latach 90. XX wieku była orędowniczką wykorzystania $\mathrm{w}$ kwestiach spornych instrumentów z zakresu soft power, aniżeli uciekanie się do rozwiązywania problemów w stosunkach międzynarodowych z wykorzystaniem siły zbrojnej.

\section{Iran wobec problemu Górskiego Karabachu w XXI wieku}

W XXI wieku Iran zaczął odczuwać zdecydowanie większe zagrożenie płynące ze sporu o Górski Karabach w porównaniu do ostatnich dekad XX wieku. Iran ze względu na swoje usytuowanie geopolityczne mógłby odegrać kluczową rolę $w$ budowaniu bezpieczeństwa międzynarodowego $\mathrm{w}$ regionie Kaukazu, szczególnie, że Teheran jest zwolennikiem poszanowania i nienaruszalności granic państw uznanych przez społeczność międzynarodową ${ }^{468}$. Wzrost zainteresowania Iranu rozwiązania napięć między Armenią a Azerbejdżanem w XXI wieku można uznać za wypadkową dwóch innych konfliktów toczących się przy irańskich granicach: w Afganistanie od października 2001 roku oraz w Iraku od marca 2003 roku. Dla Iranu działania zbrojne przy wschodniej i zachodniej granicy stanowiły zagrożenie dla bezpieczeństwa, szczególnie w kontekście obecności zachodnich, wrogich sił w tych państwach. Rozpoczęcie kolejnego konfliktu przy granicy,

${ }^{467}$ Ibidem, s. 318-319.

468 A. Ramezanzadeh, Iran's Role as Mediator in the Nagorno-Karabakh Crisis, za: https://www.vub.be/sites/vub/files/nieuws/users/bcoppiet/135ramezanzadeh.pdf, (11.02.2021), s. 6. 
było by odebrane przez Teheran jako możliwość okrążenia go z niemal każdej strony przez siły Stanów Zjednoczonych. Należy wskazać, że w tamtym czasie Departament Stanu USA pomimo napiętych relacji z Iranem stwierdził, że Iran jako sąsiad Armenii i Azerbejdżanu posiada prawo do uzyskiwania informacji o działaniach $\mathrm{w}$ ramach procesu pokojowego prowadzanego w ramach Grupy Mińskiej469.

Aktywizacja Teheranu jeśli chodzi o kwestię karabaską, nastąpiła w 2007 roku, szczególnie w kontekście współpracy z Armenią, z którą dąży do poszerzenia koordynacji projektów z zakresu energetyki oraz obronności. Początek współpracy energetycznej datuje się na rok 1992. W listopadzie 2008 roku zakończono budowę drugiej części gazociągu irańsko-armeńskiego. W 2007 roku Iran i Armenia podpisały memorandum o wsparciu logistycznym Iranu dla ormiańskiej armii. W memorandum znalazł się zapis o możliwości dostarczenia Armenii przez Iran szeroko pojętych ,,innych produktów”, co wywołało niepokój w Azerbejdżanie, ponieważ zakładano, że Teheran może dostarczać Armenii sprzęt ofensywny ${ }^{470}$. Teheran jest w stanie odpowiedzieć na niektóre potrzeby armeńskiej armii, ale problemem jest współpraca Armenii ze Stanami Zjednoczonymi i NATO, szczególnie w kontekście programu Partnerstwo dla Pokoju. Armenia jednak stara się równoważyć swoje stosunki między Teheranem i Moskwą a Waszyngtonem. Rząd Armenii wielokrotnie sprzeciwił się amerykańskim naciskom, by ograniczyć współpracę z Iranem oraz opowiadał się za prawem Islamskiej Republiki Iranu do pokojowego wykorzystania energii atomowej ${ }^{471}$. W czerwcu 2007 roku Iran ogłosił, że jest gotów mediować miedzy Armenią a Azerbejdżanem w sprawie Górskiego Karabachu. Kwestia współpracy Iranu i społeczności międzynarodowej w sprawie spornego regionu okazała się niemożliwa ze względu na kryzys spowodowany irańskim programem nuklearnym ${ }^{472}$.

W 2010 roku pojawiła się informacja o rozmieszczeniu w Górskim Karabachu wielonarodowych sił pokojowych z udziałem USA. Władze irańskie wyraziły oficjalny sprzeciw wobec obecności sił amerykańskich, szczególnie w dystrykcie Füzuli w Azerbejdżanie, który bezpośrednio graniczy z Iranem. Teheran nie doprecyzował wówczas,

\footnotetext{
469 Grupa Mińska powstała w 1992 roku w ramach OBWE w celu zakończenia sporu o górski Karabach. Zob. C. Migdalovitz, Armenia-Azerbaijan Conflict, https://www.everycrsreport.com/files/20030325_IB92109_9903b2aae5d085a21bb813dbe0a2e937e029032e.pdf, (11.02.2021), s. 14.

${ }^{470}$ P. Kwiatkiewicz, Azerbejdżan: uksztaltowanie..., op.cit., s. 366-367.

${ }^{471}$ E. Koolaee, M. H. Hafezian, The Islamic Republic of Iran and the South Caucasus Republics, „Iranian Studies" 2010, nr 3, s. 396.

${ }^{472}$ A. Dzisiów - Szuszczykiewicz, Polityka Iranu wobec Azerbejdżanu, „Bezpieczeństwo Narodowe” 2007, nr 56, s. 334 .
} 
czy jest $\mathrm{w}$ stanie zgodzić się na obecność innych sił międzynarodowych - rosyjskich czy francuskich na tym obszarze, ale podkreślił, że obecność sił międzynarodowych w Górskim Karabachu wymaga jeszcze wielu rozmów w ramach Grupy Mińskiej ${ }^{473}$.

Podczas prezydentury Mahmuda Ahmadineżada doszło do dwóch wydarzeń, które wpłynęły na relacje irańsko-azerskie. Pierwszym była organizacja przez Azerbejdżanie w 2012 roku konkursu Eurowizji, który został określony przez irańskich szyickich duchownych jako wydarzenie niemoralne i niegodne państwa muzułmańskiego. Drugim wydarzeniem było aresztowanie kilku irańskich obywateli w Azerbejdżanie, którzy planowali ataki terrorystyczne na budynki powiązane z interesami Stanów Zjednoczonych i Izraela. Iran ponowił swoje zainteresowanie rozwiązaniem sporu o Górski Karabach po objęciu stanowiska prezydenta przez Hassana Rouhaniego w 2013 roku. Wtedy irański ambasador w Azerbejdżanie ogłosił, że Islamska Republika Iranu jest gotowa podjąć negocjacje między stronami, twierdząc, że konflikt może zakończyć się dzięki działaniom dyplomatycznym, a nie militarnym ${ }^{474}$.

W 2016 roku Azerbejdżan zaczął odczuwać zagrożenie wynikające z zainteresowania Iranu rozwiązaniem kwestii Górskiego Karabachu. Baku obawiało się, że podpisanie umowy nuklearnej Iranu z grupą P5+1 (USA, Rosja, Chiny, Wielka Brytania, Francja, Niemcy) i zniesienie sankcji nałożonych na Teheran pozwoli na rozwój współpracy Teheranu z Armenią i sprzyjającą jej Rosją, szczególnie w kwestii współpracy wojskowej, co w związku ze sporem o Górski Karabach mogłoby przyczynić się do militarnej przewagi Armenii ${ }^{475}$. Niemniej, Iran pomimo współpracy $\mathrm{z}$ Armenią na wielu płaszczyznach, opowiadał się o przynależności Górskiego Karabachu do Azerbejdżanu. Przykładem takie stanowiska jest to, że szef Sztabu Generalnego Islamskiej Republiki Iranu, Mohammad Bagheri w styczniu 2019 roku ogłosił, że „Iran uważa Karabach za terytorium Azerbejdżanu i popiera integralność terytorialną Azerbejdżanu (...) Przemocowa zmiana granic jest niedopuszczalna, a Iran zawsze stoi po azerskiej stronie w tej kwestii" ${ }^{476}$. Takie deklaracje płynące ze strony Iranu wskazują, że stanowisko Iranu, co do pokojowego rozwiązania sporu

\footnotetext{
473 W dystrykcie Fùzuli siły amerykańskie przebywały w 1993 roku. Zob. R. Stepanian, Iran Against U.S. Peacekeeping Role In Karabakh, za: https:/www.azatutyun.am/a/2080247.html, (13.02.2021).

474 J. Barry, Brothers Or Comrades at Arms ? Iran's Relations with Armenia and Azerbaijan [w:] Iran in the world : president Rouhani's foreign policy, S. Akbarzadeh (red.), Basingstoke 2016, s. 65.

475 A. Jarosiewicz, $W$ objęciach Kremla. Polityka bezpieczeństwa Azerbejdżanu, za: https://www.osw.waw.pl/pl/publikacje/komentarze-osw/2016-09-01/w-objeciach-kremla-politykabezpieczenstwa-azerbejdzanu, (12.02.2021).

476 V. Doğantekin, Iran: Karabakh belongs to Azerbaijan, za: https://www.aa.com.tr/en/asia-pacific/irankarabakh-belongs-to-azerbaijan/1366528\#, (13.02.2021).
} 
o Górski Karabach w dwóch pierwszych dekadach XXI wieku nie uległo zmianie. Rozwijanie współpracy $\mathrm{z}$ Armenią $\mathrm{w}$ tak strategicznych obszarach jak bezpieczeństwo energetyczne i militarne stanowi jeden z kierunków odbudowy gospodarki Iranu po kilkudziesięciu latach sankcji międzynarodowych i powiązywanie tego rodzaju współpracy z kwestią karabaską wydaje się raczej bezpodstawne, przynajmniej z perspektywy interesów Teheranu.

\section{Iran wobec wydarzeń w Górskim Karabachu w 2020 roku}

Rok 2020 w kontekście sytuacji Iranu na arenie międzynarodowej był jednym z najtrudniejszych w historii współczesnej tego państwa. Kolejne wydarzenia, które dotykały Teheran, poczynając od zabicia generała Kassema Sulejmaniego w Iraku, katastrofy ukraińskiego samolotu pasażerskiego, napięć ze Stanami Zjednoczonymi poprzez pandemię koronawirusa, kończąc na konflikcie o Górski Karabach spowodowały, że Iran zaczął odczuwać realne zagrożenie militarne dla swojego bezpieczeństwa. 27 września 2020 roku doszło do eskalacji napięcia między Armenią i Azerbejdżanem o Górski Karabach, kiedy to wojska azerbejdżańskie zdecydowały się na ofensywę na północy linii kontaktowej, która oddziela Górski Karabach od Azerbejdżanu oraz na granicy armeńsko-azerbejdżańskiej na południu. W kolejnych dniach konfliktu siły azerbejdżańskie odcięły obszar Karabachu od granicy z Iranem ${ }^{477}$. Siłom azerbejdżańskim udało się zająć około $30 \%$ terytorium Górskiego Karabachu, a 9 listopada 2020 roku zajęto miasto Susza, które jest uznawane za bramę w głąb Górskiego Karabachu ${ }^{478}$.

Rozpoczęcie działań zbrojnych w Górskim Karabachu postawiło Iran w bardzo niewygodnym położeniu. Irańskie ministerstwo spraw wewnętrznych jasno zakomunikowało, że w sytuacji, gdy walki między Armenią a Azerbejdżanem przeniosą się na terytorium Islamskiej Republiki Iranu, wówczas Teheran dokona odpowiednich kroków w celu zapewnienia bezpieczeństwa międzynarodowego. Już kilka dni po rozpoczęciu działań zbrojnych, czterech najważniejszych przywódców modlitewnych Iranu, stanowiących osobistych wysłanników Najwyższego Przywódcy wydało oświadczenie, w którym udzieliło poparcia dla sił Azerbejdżanu, które mają według nich mają prawo do zakończenia „ormiańskiej okupacji” ziemi islamu, jaką jest Górski Karabach. Ponadto, oświadczenie miało

477 A. M. Dyner, Wojskowy wymiar konfliktu o Górski Karabach, za: https://pism.pl/publikacje/Wojskowy_wymiar_konfliktu_o_Gorski_Karabach, (13.02.2021).

${ }^{478}$ A. Legieć, Rozejm w Górskim Karabachu, za: https://pism.pl/publikacje/Rozejm_w_Gorskim_Karabachu, (13.02.2021). 
wpłynąć także na sytuację w Irańskim Azerbejdżanie, gdzie mniejszość azerska zaczęła opowiadać się za działaniami wojsk azerbejdżańskich ${ }^{479}$.

Hassan Rouhani w rozmowie z premierem Armenii, stwierdził, że to Erywań musi zakończyć spór o Górski Karabach ${ }^{480}$. W podobnym tonie wyspowiadał się doradca Najwyższego Przywódcy ds. bezpieczeństwa narodowego, Ali Akbar Velayati i rzecznik rządu, Ali Rabiei, którzy wezwali Armenię do wycofania się spod granicy z Azerbejdżanem, która jest uznawana przez Organizację Narodów Zjednoczonych oraz odwołali się do jednej $\mathrm{z}$ rezolucji Rady Bezpieczeństwa z lat 90. XX wieku, w której wskazano, że obecność sił armeńskich w Górskim Karabachu jest „okupacją"481. Sam Najwyższy Przywódca w wystąpieniu emitowanym w irańskiej telewizji państwowej 3 listopada 2020 roku powiedział: „Ziemie Azerbejdżanu okupowane przez Armenię powinny zostać wyzwolone i zwrócone Azerbejdżanowi”, przy czym podkreślił, że Ormianie zamieszkujący Górski Karabach powinni zostać bezdyskusyjnie objęci ochroną ${ }^{482}$.

W związku z narastającym konfliktem Iran zaczął odczuwać bezpośrednie zagrożenie płynące z działań zbrojnych, gdy na terytorium Islamskiej Republiki Iranu zaczęły spadać zarówno azerbejdżańskie, jak i armeńskie pociski rakietowe i artyleryjskie ${ }^{483}$, także jej przestrzeń powietrzna była naruszana przez drony. Skutkowało to tym, że w połowie października 2020 roku Iran przeprowadził w rejonie granicy z Azerbejdżanem i Armenią manewry obrony powietrznej, co miało stanowić jednoznaczny sprzeciw Teheranu wobec naruszania przez strony konfliktu irańskiej suwerenności i integralności terytorialnej. Ponadto, Iran na drogach dojazdowych do granicy z Azerbejdżanem oraz Górskim

$479 \quad$ K. Ochman, Ostrożna polityka Iranu $w$ konflikcie o Górski Karabach, za: https://kierunekkaukaz.pl/2020/10/13/ostrozna-polityka-iranu-w-konflikcie-o-gorski-karabach/, (13.02.2021).

${ }^{480}$ Iran chce mediacji ws. konfliktu w Górskim Karabachu, za: https://www.wnp.pl/rynki-zagraniczne/iran-chcemediacji-ws-konfliktu-w-gorskim-karabachu,424642.html, (13.02.2021).

481 K. Ochman, Ostrożna polityka Iranu $w$ konflikcie o Górski Karabach, za: https://kierunekkaukaz.pl/2020/10/13/ostrozna-polityka-iranu-w-konflikcie-o-gorski-karabach/, (13.02.2021).

482 B. Daragahi, Nagorno-Karabakh: An unexpected conflict that tests and perplexes Iran, za: https:/www.atlanticcouncil.org/blogs/iransource/nagorno-karabakh-an-unexpected-conflict-that-tests-andperplexes-iran/, (13.02.2021).

483 Dowódca Korpusu Strażników Rewolucji Islamskiej, Hassan Salami po jednym z incydentów z udziałem pocisków rakietowych stwierdził, że „Jakakolwiek niepewność i zagrożenie na naszych granicach, które szkodzą bezpieczeństwu psychicznemu i pokojowi naszych obywateli, jest nie do przyjęcia". Zob. B. Daragahi, Nagorno-Karabakh: An unexpected conflict that tests and perplexes Iran, za: https:/www.atlanticcouncil.org/blogs/iransource/nagorno-karabakh-an-unexpected-conflict-that-tests-andperplexes-iran/, (13.02.2021). 
Karabachem ustanowił kontrole bezpieczeństwa z wykorzystaniem ciężkiego uzbrojenia oraz systemami obrony przeciwlotniczej ${ }^{484}$.

Należy zadać pytanie jaką i czy w ogóle jakąś rolę odegrał Iran w rozmowach pokojowych, które przyczyniły się do podpisania zawieszenia broni między Armenią i Azerbejdżanem? Miesiąc po rozpoczęciu konfliktu, wiceminister spraw zagranicznych Iranu został oddelegowany do rozpoczęcia działań dyplomatycznych mających na celu zakończenia konfliktu. Brał on udział w rozmowach w Baku, Erywaniu, Moskwie i Ankarze, gdzie informował o irańskich obawach, co do zachwiania ładu i bezpieczeństwa $\mathrm{w}$ regionie ${ }^{485}$. Przedstawiono także irańskie propozycje zakończenia konfliktu, które zawierały między innymi: zapewnienie praw ludności, ustanowienie kanałów komunikacji, stworzenie mechanizmu dla krajów regionu do monitorowania realizacji inicjatywy. Iran zapowiedział też chęć współpracy w przeciwdziałaniu zagrożeniom terrorystycznym w Górskim Karabachu ${ }^{486}$. Rozmowy między Armenią a Azerbejdżanem były prowadzone przez Rosję przy nieoficjalnym udziale Turcji, co skutkowało tym, że Iran został praktycznie wyłączony z prac nad porozumieniem pokojowym. W wyniku porozumienia zawartego 10 listopada 2020 roku siły armeńskie skapitulowały oraz wydano decyzję o rozmieszczeniu rosyjskich sił pokojowych na terenie Górskiego Karabachu, w regionach, gdzie występuje mniejszość ormiańska. Takie rozwiązanie powoduje, że Iran musi dokonać zmian w swojej polityce wobec północno-zachodnich sąsiadów oraz skupić się na zabezpieczeniu militarnym granicy z Azerbejdżanem, co wynika głównie z wyżej wymienionych sytuacji zagrażających bezpieczeństwu Iranu, do jakich doszło w czasie konfliktu ${ }^{487}$. Dla władz irańskich konieczność zabezpieczenia kolejnej części granicy, tym razem na północno-zachodniej części kraju powoduje osłabienie koncentracji Teheranu na innych kluczowych w kontekście irańskich interesów regionów - przede wszystkim Zatoki Perskiej, Syrii czy Jemenu oraz zwiększenia kosztów na obronność, co szczególnie w okresie kryzysu gospodarczego w Iranie oraz pandemii koronawirusa stanowi wyzwanie ekonomiczne.

484 Ł. Golowanow, Górski Karabach: 28. dzień wojny, Iran zabezpiecza granice z Azerbejdżanem, za: https://www.konflikty.pl/aktualnosci/wiadomosci/gorski-karabach-28-dzien/, (13.02.2021).

485 B. Daragahi, Nagorno-Karabakh: An unexpected conflict that tests and perplexes Iran, za: https://www.atlanticcouncil.org/blogs/iransource/nagorno-karabakh-an-unexpected-conflict-that-tests-andperplexes-iran/, (13.02.2021).

486 Araghchi held very good' talks during regional tour: Zarif, za: https:/www.tehrantimes.com/news/454169/Araghchi-held-very-good-talks-during-regional-tour-Zarif, (13.02.2021).

${ }^{487}$ L. Coffey, Iran the big loser in Nagorno-Karabakh war, za: https://www.arabnews.com/node/1762626, (13.02.2021). 
Wydarzenia z 2020 roku oprócz tego, że stanowiły zagrożenie dla bezpieczeństwa Iranu, paradoksalnie dają Teheranowi oraz Baku nowe możliwości współpracy. W połowie stycznia 2021 roku minister spraw zagranicznych Iranu, Mohammad Javad Zarif podczas spotkania z prezydentem Azerbejdżanu zapowiedział, że Iran pomoże Baku w odbudowie zniszczonych w wyniku konfliktu zbrojnego obszarów odebranych Armenii. Ilham Alijew z zadowoleniem przyjął ofertę, zapraszając irańskie firmy do przyłączenia się do odbudowy siedmiu okręgów otaczających sporny region Górskiego Karabachu ${ }^{488}$. Chęć współpracy w tak strategicznych obszarach jak budownictwo, energetyka czy ochrona zabytków może spowodować zmniejszenie napięć między Teheranem a Baku oraz zrównoważenie przez Iran wpływów takich państw jak Turcja, Stany Zjednoczone czy Izrael w Azerbejdżanie na swoją korzyść.

\section{Wnioski}

Dla Iranu kluczową rolą jest utrzymanie stabilności społecznej wewnątrz państwa. Posiadając na swoim terytorium zarówno mniejszość ormiańską, jak i azerską, wyzwanie dla władz irańskich jest ogromne, szczególnie, że Azerowie są jedną z najbardziej wpływowych grup społecznych w Iranie. Azerowie mają duży wpływ na teherański bazar, który posiada ważne znaczenie nie tylko gospodarcze, ale i polityczne ${ }^{489}$. Dla Iranu określenie się oficjalnie po jednej ze stron konfliktu w XXI wieku jest niebywale trudne, a sam fakt rozwoju współpracy z chrześcijańską Armenią, kosztem muzułmańskiego i szyickiego Azerbejdżanu wynika $\mathrm{z}$ dwóch przesłanek. Po pierwsze, dla Teheranu problemem w relacjach z Azerbejdżanem jest to, że Baku wspiera program NATO - Partnerstwo dla Pokoju czy Organizację na rzecz Demokracji i Rozwoju (GUAM), co jednoznacznie pokazuje, że dla Azerbejdżanu ważnym kierunkiem polityki zagranicznej jest współpraca z Europą i USA. Po drugie - system obowiązujący w Azerbejdżanie. Azerbejdżan podobnie jak Iran jest państwem w większości szyickim, jednak w przeciwieństwie do Iranu, republiki islamskiej, Baku obrał turecki model państwa świeckiego ${ }^{490}$.

\footnotetext{
${ }^{488}$ Z. Agayev, Iran Offers to Rebuild Azerbaijani Areas Won Back in Armenia War, za : https:/www.bloomberg.com/news/articles/2021-01-25/iran-offers-to-rebuild-azerbaijani-areas-won-back-inarmenia-war, (13.02.2021).

${ }^{489}$ Najwyższy Przywódca Iranu, Ali Chamenei ze strony ojca posiada pochodzenie azerskie. Zob. Iran chce mediacji ws. konfliktu w Górskim Karabachu, za: https://www.wnp.pl/rynki-zagraniczne/iran-chce-mediacji-wskonfliktu-w-gorskim-karabachu,424642.html, (13.02.2021).

${ }^{490}$ A. Dzisiów - Szuszczykiewicz, Polityka Iranu wobec Azerbejdżanu..., op. cit., s. 337-338.
} 
Dla Iranu katastrofalne skutki mogłoby mieć umiędzynarodowienie konfliktu i zaangażowanie w niego następujących państw: Turcji, która opowiada się po stronie Azerbejdżanu, Rosji, która współpracuje z Armenią oraz Stanów Zjednoczonych i Izraela dla których Azerbejdżan jest kluczowym partnerem w regionie. Iran mając w różnym stopniu, ale napięte relacje $\mathrm{z}$ każdym $\mathrm{z}$ tych państw, uznaje zaangażowanie ich $\mathrm{w}$ sprawy bezpośrednio wiążące się z irańskim bezpieczeństwem za zagrożenie dla suwerenności i integralności Islamskiej Republiki Iranu. I o ile zagrożenia płynące ze strony USA i Izraela jest wciąż podkreślane przez władze irańskie, które od lat próbują stworzyć system obrony przed potencjalnym atakiem ze strony tych państw, to pojawienie się ponad 2 tysięcy rosyjskich żołnierzy w okolicy około 100 kilometrów od terytorium Iranu tworzy nowe wyzwanie dla władz irańskich. W przypadku Turcji, napięcia na linii Teheran - Ankara wynikają z problematyki wojny w Syrii i tego, ze oba państwa wspierają przeciwne strony walczące. Ponadto, doniesienia, że Azerbejdżan wydał zgodę na rozmieszczenie syryjskich najemników, którzy nie tylko są sunnitami, ale walczą przeciwko reżimowi Baszara al-Assada spowodowały konsternację władz irańskich, które obawiają się przemieszenia się antyirańskich bojówek na swoje terytorium ${ }^{491}$.

Iran będzie w najbliższym czasie baczniej przyglądać się zmieniające się sytuacji w Górskim Karabachu. O ile sam konflikt zbrojny jest faktycznym zagrożeniem nie tylko dla Teheranu, ale i dla całego regionu, to kwestia zaangażowania się innych państw o ambicjach mocarstwowych, powoduje, że Iranowi może być trudno zbudować sojusz, który miałby poprzeć jedną ze stron konfliktu, szczególnie, że Teheran od lat balansuje między Baku a Erywaniem, powoduje, że żadne z tych państw nie może jednoznacznie określić Iranu jako państwa sojusznika w sporze o Górski Karabach.

\section{Streszczenie:}

Spór o Górski Karabach stanowi jedno z zagrożeń dla bezpieczeństwa Iranu. Iran od kilkudziesięciu lat stara się prowadzić działania dyplomatyczne mające na celu zakończenie sporu między Armenią a Azerbejdżanem o sporny obszar, dążąc do uzyskania statusu głównego negocjatora między stronami. Dla władz irańskich kolejny konflikt zbrojny przy granicy państwa w połączeniu z liczną i wpływową mniejszością azerską stanowi zagrożenie

491 B. Daragahi, Nagorno-Karabakh: An unexpected conflict that tests and perplexes Iran, za: https:/www.atlanticcouncil.org/blogs/iransource/nagorno-karabakh-an-unexpected-conflict-that-tests-andperplexes-iran/, (13.02.2021). 
dla stabilności państwa. Przyłączenie Górskiego Karabachu do Republiki Azerbejdżanu jest odbierane przez Teheran jako potencjalny impuls dla irańskich Azerów do połączenia północnych ostanów z Azerbejdżanem, a to wiąże się z zachwianiem równowagi w regionie. Niniejszy artykuł ma na celu wskazanie działań Iranu mających na celu zakończenie sporu o Górski Karabach, szczególnie w latach 90. XX wieku i dwóch pierwszych dekadach XXI wieku. W artykule $\mathrm{w}$ celu analizy powyższego problemu zostały wykorzystane następujące metody badawcze: analiza historyczna, metoda decyzyjna oraz synteza.

\section{Słowa kluczowe:}

Górski Karabach, Iran, Azerowie, integralność terytorialna

\section{Keywords:}

Nagorno-Karabakh, Iran, Azerbaijanis, territorial integrity

\section{Bibliografia:}

1. Adamczewski P., Górski Karabach w polityce niepodległego Azerbejdżanu, Warszawa 2012.

2. Agayev Z., Iran Offers to Rebuild Azerbaijani Areas Won Back in Armenia War, za : https://www.bloomberg.com/news/articles/2021-01-25/iran-offers-to-rebuildazerbaijani-areas-won-back-in-armenia-war, (13.02.2021).

3. Araghchi held 'very good' talks during regional tour: Zarif, za: https://www.tehrantimes.com/news/454169/Araghchi-held-very-good-talks-duringregional-tour-Zarif, (13.02.2021).

4. Barry J., Brothers Or Comrades at Arms? Iran's Relations with Armenia and Azerbaijan [w:] Iran in the world: president Rouhani's foreign policy, S. Akbarzadeh (red.), Basingstoke 2016.

5. Coffey L., Iran the big loser in Nagorno-Karabakh war, za: https://www.arabnews.com/node/1762626, (13.02.2021).

6. Curanović A., Religie, kościoly i konflikty międzywyznaniowe w regionie Kaukazu [w:] Wprowadzenie do studiów wschodnioeuropejskich. Tom 4. Armenia, Azerbejdżan, Gruzja - przeszłość i teraźniejszość, M. Korzeniowski, D. Tarasiuk, K. Latawiec (red.), Lublin 2013.

7. Daragahi B., Nagorno-Karabakh: An unexpected conflict that tests and perplexes Iran, za: https:/www.atlanticcouncil.org/blogs/iransource/nagorno-karabakh-anunexpected-conflict-that-tests-and-perplexes-iran/, (13.02.2021).

8. Doğantekin V., Iran: Karabakh belongs to Azerbaijan, za: https://www.aa.com.tr/en/asia-pacific/iran-karabakh-belongs-to-azerbaijan/1366528\#, (13.02.2021). 
9. Dyner A. M., Wojskowy wymiar konfliktu o Górski Karabach, za: https://pism.pl/publikacje/Wojskowy_wymiar_konfliktu_o_Gorski_Karabach, (13.02.2021).

10. Dzisiów - Szuszczykiewicz A., Polityka Iranu wobec Azerbejdżanu, „Bezpieczeństwo Narodowe" 2007, nr 5-6.

11. Franz M., Czy Azji grozi kolejna wojna, tym razem w basenie Morza Kaspijskiego?, „Nowa Polityka Wschodnia” 2013, nr 2.

12. Golowanow Ł., Górski Karabach: 28. dzień wojny, Iran zabezpiecza granice z Azerbejdżanem, za: https://www.konflikty.pl/aktualnosci/wiadomosci/gorskikarabach-28-dzien/, (13.02.2021).

13. Iran chce mediacji ws. konfliktu w Górskim Karabachu, za: https://www.wnp.p1/rynkizagraniczne/iran-chce-mediacji-ws-konfliktu-w-gorskim-karabachu,424642.html, (13.02.2021).

14. Jarosiewicz A., $W$ objęciach Kremla. Polityka bezpieczeństwa Azerbejdżanu, za: https://www.osw.waw.pl/pl/publikacje/komentarze-osw/2016-09-01/w-objeciachkremla-polityka-bezpieczenstwa-azerbejdzanu, (12.02.2021).

15. Koolaee E., Hafezian M. H., The Islamic Republic of Iran and the South Caucasus Republics, „Iranian Studies"' 2010, nr 3.

16. Kwiatkiewicz P., Azerbejdżan: uksztaltowanie niepodległego państwa, Toruń 2009.

17. Legieć A., Rozejm $\quad$ w Górskim Karabachu, za: https://pism.pl/publikacje/Rozejm_w_Gorskim_Karabachu, (13.02.2021).

18. Mahmudlu C., Abilov S., The peace-making process in the Nagorno-Karabakh conflict: why did Iran fail in its mediation effort?, „Journal of Contemporary Central and Eastern Europe'" 2018, nr 26.

19. Mechtijew R., Dziesięć lat, które zmienity Azerbejdżan 2003-2013, Wydawnictwo Adam Marszałek, Toruń 2016.

20. Migdalovitz C., Armenia-Azerbaijan Conflict, https://www.everycrsreport.com/files/20030325_IB92109_9903b2aae5d085a21bb813 dbe0a2e937e029032e.pdf, (11.02.2021).

21. Modrzejewska-Leśniewska J., Konflikt armeńsko-azerbejdżański 1990-2006 [w:] Konflikty kolonialne i postkolonialne w Afryce i Azji 1869-2006, P. Ostaszewski (red.), Warszawa 2006.

22. Ochman K., Ostrożna polityka Iranu w konflikcie o Górski Karabach, za: https://kierunekkaukaz.pl/2020/10/13/ostrozna-polityka-iranu-w-konflikcie-o-gorskikarabach/, (13.02.2021).

23. Ramezanzadeh A., Iran's Role as Mediator in the Nagorno-Karabakh Crisis, za: https://www.vub.be/sites/vub/files/nieuws/users/bcoppiet/135ramezanzadeh.pdf, (11.02.2021).

24. Rzepka M., Polityka zagraniczna Islamskiej Republiki Iranu [w:] Wprowadzenie do polityki zagranicznej muzułmańskich państw Bliskiego Wschodu i Afryki Pólnocnej, M. Woźniak-Bobińska, A. M. Solarz (red.), Warszawa 2018.

25. Stepanian R., Iran Against U.S. Peacekeeping Role In Karabakh, za: https://www.azatutyun.am/a/2080247.html, (13.02.2021). 
26. Tarasiuk D., Procesy narodowotwórcze, narody i problemy narodowościowe $w$ regionie Wprowadzenie do studiów wschodnioeuropejskich. Tom 4. Armenia, Azerbejdżan, Gruzja - przeszłość i teraźniejszość, M. Korzeniowski, D. Tarasiuk, K. Latawiec (red.), Lublin 2013 